从而使图上作业法逐步形成了一个,具有土生士长特 点的理骊系統。此外，数学工作者与广大工农翠众 相結合,在生产实践中依据特定問題的需要,創造出 各式各样的理論和方法, 如劳力組合的效率比定理、 汽車运輸的方块接龙法等等。曲皋师范学院师生还 結合研究与解决人民公㼛中的一系列的数学問題, 写出了“公社数学”一书，为我国数学在农业方面的 应用和理諭上的发展开辟了新的方向。

会議䚿为,山东的主要經驗是依靠党的領导好、 宣传普及发动翠众好、四同三結合做的好、数学工 作者大协作大联合做的好。与会代表一致表示要“学 山东、赶山东、超山东”，把运筹学綫性规划的推 广与应用在全国范围內推向一个新的高潮。

[陈新洲]

\section{数学工作者深入公社大搞 数学为生产服务活动}

在全国各地热烈响应党中央的号召，各行各业 全面支援农业的翠众运动中，中国科学院数学研究 所的部分同志,在所項导的亲自带領下,为貫彻党的 理論联柔实际,科学为生产服务的方針,在北京郊区 永丰人民公社配合麦收工作，应用数学中的綫性規 划方法，制訂出最合理地使用收割机、脫粒机、人 力、車轅等調度方案, 取得了很大的效果。

在永丰人民公到摸到了一定的实际工作 經 驗 后, 数学研究所的同志們又在北京市委的直接領导 下，以数学研究所和力学呼究所的四十余位同志为 骨干，組織了中国科学技术大学、北京师范学院、 北京师范专科学校、北京工农师范学院、北京农业 机峨化学院五所高等院校一千余名师生, 分赴北京 郊区各人民公社，大搞科学为生产服务，推广和普 及数学的活动。

同志們到达农村后，紧紧地依靠公社党組織的 領导，和社員同生活，同劳动，同商量，深入田間 进行調查研究。在制訂收割机的調度方案时, 充分 了解到小麦的分布地区、亩数和成熟期，以及收割 机站的位置与各麦田之間的道路和距离等, 扭且反 复訪間老农和生产技术員，将所得的資料画在地 图上，然后应用綫性規划中的图上作业法（我国帮
众創造的一种計算方法），制訂出了收割机的調度 方䓩。公社原訂計划是两个星期完成麦收工作，而 新制訂的收割机調度方慗只須要一个星期就能完成 麦收工作。因此，新方案比公塥原訂計划节約了 $50 \%$ 的时間和人力。与此同时，同志們还与北京 业大学、北京气象学校的师生进行了大协作, 大配 合，保証了公社麦收的胜利完成。

在选取最优麦場位踢时，同志們不是单純地应 用数学方法，而是从客覌实际出发，考虑到地形、 水源、运輸和管理以及旧有麦場地的充分利用等条 件，使制訂的最优麦場方案更加切合实际情况。根 据北京郊区四个县的統計，实行新方案后，本均可 以节約劳动力、运輸力 45-50\%，提前一牛时間把 小麦运到麦場，在相当程度上解决了劳动力和运䡕 力不足的困难。

为了使数学在生产实践中継續发揮它应有的作 用，接着以农业中学、紅专大学和农业干部为对 象，展开了广泛的推广和普及数学活动。䛍授了緎 性規划中的图上作业法，最优麦場选置等方法。为 了便于推广和普及数学方法, 华罗庚所长还特意将 “图上作业法”写成了为壁众易于接受的口訣形式:

$\begin{array}{ll}\text { 流向画右旁, } & \text { 对流不应当, } \\ \text { 里圈与外圈, } & \text { 都无牛园长。 }\end{array}$

将最优麦場选置法写成:

道路无迴环，看各端，

最小进一站。

道路有迥环，每圈甩一段，

化成无迴环，然后照样算;

㫣法有不同，結果-D算，

算后再比較，最优立可断。

在推广和普及数学方法的过程中, 把数学方法 写成口訣或快板的形式，不仅便于記忆，而且便于 理解和掌握数学方法的实稹, 因此为掌众所欢迎。

通过这次深入农村实际，同志們深深体会到农 村中的数学問題是非常丰富和具体的。比如: 有一 块麦田的边界为任意曲紷，如何在此曲确定一 点最优麦場？又如，有分散的面积不同、成熟期各 异的麦田，收割机站与各麦田之間有一定的网絡路 綫联系着，如何調度定量的收割机，使收获的小麦 最多，所花费的时間最少? 再如，如何設計万头猪 
場的管道，使得輸入猪食和輸出猪肥自动化，抹且 管道最短，猪場所占地面最省？建設共产主义的新 农村，如何进行居民点和园田化的全面规划等 等。 这些問题都是在一定的的束条件下，求最优解的数 学問題。

以数学工作者为主的千人大軍，深入到农村人 民公䎟，大搞数学为生产服务，推广和普及数学的 活动的实践証明，数学在农村人民公社中，在生产 实践活动中是大有用处的，同时，生产实践也为数 学的发展, 升辟了新的广閏的途径。

\section{聶善長}

(中国科学院数学研究所)

\section{迅速等天文科学的高萃}

6 月中旬，在南京召开了中国科学院紫金山天 交台学术委員会魹中国天文学会全国工作会議。这 次会镜在总結过去三年多来天文工作成績和經驗的 基础上，着重研究了今后天文学发展规划的問題， 即如何買彻大解放、大协作、大学鳴的精神，迅速 登天文科学高䋆，努力为补会主义建設服务的問 題。出席会镜的有来自全国各地的天女科学工作者 和高等院校的有关数师代表共一百多人。中国科学 院数学物理学化学部副主任惲子强参加了会議讲作 了重要指示，全国科学技术协会的代表高济宇和中 国科学院江苏分院副院长周資衡都出席了会議开幕 式，抹作了既話。

会㼁期間,紫金山天文台台长张帮以“高举毛 泽东思想紅旗, 更快登天文科学的高峯”为題作了 学术委員会的工作报告，中国天文学会副理事长勒 文签作了天文学会的会务报告。会議还就地方筹办 天文事业問題、天文仪器制造問題、千部培养問題、 天文学报編輯出版問題等进行了发言和討論。这次 会議还广泛开展了学术活动, 在天体物理和天体測 量两大专业系統的报告会中，共收到和宣諸了七十 余篇学术論文，其中包括射电天文的研究报告、变 星和不稳定星的覌湘研究、太阳耀斑出現规律、地 球自轉速度的变化和地极移动等問題的探討。值得 称道的是，所有这些，百分之九十都是青年的工作。 此外,“射电天文学的后頋与前䀡”、“人造卫星和宇
宙火箭”、“天体演化学的进展”、“天文敉学改革” 四篇报告，更引起了代表們极大的兴趣和注意。

会議䚿埧地审訂了今后三年和八年的天女学发 展规划。天文学会抹制訂了新会章，打破泊有会员 資历的規定，向广大翌众开門; 聕选了中国天文学 会理事八人，組成了包括有青老天文工作者和党的 負責干部参加的新的理事会，扭在理事会下設正变 星专业小組，以組織推动全国的变星观测呼究工作。

紫金山天文台学术委員会和中国天文学会第一 次代表大会是在 1957 年初召开的。三年多来，党 加强了对天文事业的領导，經过伟大的整风运动和 反右派斗爭，全国天文界受到了一次深到的政治上 和思想上的社会主义教育，在总路綫的光輝照知和 全国大跃进形势的鼓舞下，天文科学工作发生了深 到的变化，在开辟新学科、填补空白部門、独立制 造天文仪器、扩充干部队伍等方面取得了很大的成 績, 与会代表对此感到异常兴奋和鼓舞。另一方面, 代表椚誩为，从我国社会主义建設飞跃发展的形势 和要求，从天文学的国际先进水平看来，我国目前 天文学的发展还是远沅不够的。在这宇宙航行的伟 大时代里, 天文科学負有独特的使命。我們一定要 迅速地、根本地改变天女学的落后面貌，澈底清除 那些抽象的为天文而天文的唯心主义覌点。天文学 的研究必須理論联系实际, 必須强調具有明确的社 会目的性, 只有这样天文学才能得到一速的发展。

我国地方性的天文事业也在逢勃发展。会議期 間, 山东、吉林、河南、福建等省和許多高等院校 代表, 都热情地营报了他們已經或正在筹办天文 台、天文专业的經过情况。他們的发言特別令人振 龺。

六十年代是自然科学发展史上的社会主义时 代。由于宇宙航行新紀元的揭示, 由于新兴的射电 天文学的飞跃发展, 由于无䋐电电子学等新技术在 天文学上的大量应用, 古老的天文学正面临着一个 洶涌澎湃的科学革命高潮。与会代表滿怀信心，一 致表示要: 訩清形势, 明确任务, 坚决高举毛泽东 思想紅旗, 大解放，大协作，大爭鳴，尽速杽登天 文科学的最高笔。

[中国科学院紫金山天文台通訊組] 